\title{
Effects of sodium and chloride source and concentration on nursery pig growth performance $^{1}$
}

\author{
Dwight J. Shawk, ${ }^{\dagger}$ Mike D. Tokach, ${ }^{\dagger}$ Robert D. Goodband, ${ }^{\dagger, 2}$ Steve S. Dritz, ${ }^{\dagger, \oplus}$ \\ Jason C. Woodworth, ${ }^{\dagger}$ Joel M. DeRouchey, ${ }^{\dagger}$ Annie B. Lerner, ${ }^{\dagger}$ Fangzhou Wu, ${ }^{\dagger}$ \\ Carine M. Vier, ${ }^{\dagger}$ Madison M. Moniz, ${ }^{\dagger}$ and Kayla N. Nemechek ${ }^{\dagger}$
}

$\dagger$ Department of Animal Sciences and Industry, College of Agriculture; and Department of Diagnostic
Medicine/Pathobiology, College of Veterinary Medicine, Kansas State University, Manhattan 66506-0210

\begin{abstract}
Three studies were conducted to determine the effects of source and concentration of $\mathrm{Na}$ and $\mathrm{Cl}$ on pig growth performance from 7 to $12 \mathrm{~kg}$. In all three experiments, pigs were fed a common diet $(0.33 \% \mathrm{Na}$ and $0.77 \% \mathrm{Cl})$ for 7 or 8 $\mathrm{d}$ after weaning then randomly assigned to dietary treatments. In Exp. 1, 360 mixed-sex pigs were used in a 14-d study with 15 replications per treatment and six pigs per pen. Treatments included a $10 \%$ dried whey diet with $0.60 \%$ added salt $(0.37 \% \mathrm{Na}$ and $0.75 \% \mathrm{Cl}$ ); or three diets with $7.2 \%$ crystalline lactose with either: $0.35 \%$ added salt $(0.18 \%$ $\mathrm{Na}$ and $0.47 \% \mathrm{Cl}) ; 0.78 \%$ added salt $(0.35 \% \mathrm{Na}$ and $0.72 \% \mathrm{Cl}$ ); or $1.15 \% \mathrm{NaHCO}_{3}$ and $0.40 \%$ $\mathrm{KCl}(0.35 \% \mathrm{Na}$ and $0.45 \% \mathrm{Cl})$. Pigs fed the $0.78 \%$ added salt-lactose diet had greater $(P<0.05)$ ADG than pigs fed the $0.35 \%$ added salt-lactose diet, with others intermediate. In Exp. 2, 360 barrows were used in a 14-d study with 12 replications per treatment and five pigs per pen. Treatments included two added salt diets (providing 0.13\% $\mathrm{Na}$ and $0.35 \% \mathrm{Cl}$ or $0.35 \% \mathrm{Na}$ and $0.68 \% \mathrm{Cl}$ ), three diets with $\mathrm{Na}$ and $\mathrm{Cl}$ provided by $\mathrm{KCl}$ and $\mathrm{NaHCO}_{3}(0.13 \%, 0.35 \%$, or $0.57 \% \mathrm{Na}$ and $0.50 \%$ Cl) or a diet with $\mathrm{NaHCO}_{3}$ and $\mathrm{CaCl}_{2}(0.35 \% \mathrm{Na}$
\end{abstract}

and $0.50 \% \mathrm{Cl}$ ). Regardless of $\mathrm{Na}$ source, ADG and ADFI increased (quadratic, $P<0.05$ ) as dietary $\mathrm{Na}$ increased from $0.13 \%$ to $0.35 \%$, with no further benefits observed thereafter. There was no evidence for differences among pigs fed $\mathrm{NaCl}$ or $\mathrm{NaHCO}_{3}$ nor evidence for differences among pigs fed the different $\mathrm{Na}$ and $\mathrm{Cl}$ sources at similar concentrations. In Exp. 3, 300 pigs were used in a 21-d trial with 10 replications per treatment and five pigs per pen. Treatments included a control diet with added salt to provide $0.33 \% \mathrm{Na}$ and $0.55 \% \mathrm{Cl}$ or five diets with $0.33 \% \mathrm{Na}$ and added $\mathrm{KCl}$ to provide $0.09,0.21,0.32,0.45$, or $0.55 \% \mathrm{Cl}$. ADG and G:F increased (quadratic, $P<0.035$ ) as $\mathrm{Cl}$ increased from $0.09 \%$ to $0.32 \%$. Pigs fed the control diet (added salt) and the $0.55 \% \mathrm{Cl}$ diet had similar ADG. For ADG and ADFI, the broken line linear model indicated a breakpoint of $0.23 \%$ $\mathrm{Cl}$. For G:F, the quadratic polynomial model suggested the maximum at $0.38 \% \mathrm{Cl}$. In conclusion, 7 to $12 \mathrm{~kg}$ pigs fed diets that contained at least $0.35 \% \mathrm{Na}$ and $0.38 \% \mathrm{Cl}$ had greater ADG and $\mathrm{G}: \mathrm{F}$ compared to pigs fed diets with lower concentrations and minimal effects were observed among the sources of $\mathrm{Na}$ or $\mathrm{Cl}$ used in these studies.

Key words: chloride, pig, salt, sodium

(C) The Author(s) 2018. Published by Oxford University Press on behalf of the American Society of Animal Science. All rights reserved. For permissions, please e-mail: journals.permissions@oup.com.

J. Anim. Sci. 2019.97:745-755
doi: 10.1093/jas/sky429

\section{INTRODUCTION}

${ }^{1}$ Contribution No. 19-015-J from the Kansas Agricultural Experiment Station, Manhattan 66506-0210.

${ }^{2}$ Corresponding author: goodband@ksu.edu

Received August 31, 2018.

Accepted November 2, 2018.

Two of the most common electrolytes found in the body are $\mathrm{Na}$ and $\mathrm{Cl}$. Each mineral has several specific roles including maintaining homeostasis of water and electrolytes and acid-base balance. 
Sodium regulates cellular osmolarity and plasma volume and is critical in cellular transport systems, muscle contraction, and nerve impulse. Chloride is a component of $\mathrm{HCl}$, which is critical in the activation of pepsin. The NRC (1998) requirement estimates for $\mathrm{Na}$ and $\mathrm{Cl}$ are $0.20 \%$ and $0.20 \%$ for 5 to $10 \mathrm{~kg}$ pigs and $0.15 \%$ and $0.15 \%$ for 10 to $20 \mathrm{~kg}$ pigs. While evaluating $\mathrm{Na}$ and $\mathrm{Cl}$ independently, Mahan et al. (1996) observed improvements in ADG up to a dietary $\mathrm{Na}$ and $\mathrm{Cl}$ concentrations of $0.34 \%$ and $0.50 \%$ in pigs weighing $\sim 6$ to $9 \mathrm{~kg}$. Mahan et al. (1999) noted improvements in ADG up to a dietary $\mathrm{Cl}$ concentration of $0.45 \%$ in 7 to $12 \mathrm{~kg}$ pigs; however, in two additional studies, improvements in ADG and $\mathrm{N}$ retention were observed up to a dietary $\mathrm{Cl}$ concentration of only $0.32 \%$ and $0.38 \%$ in pigs weighing $\sim 6$ to $13 \mathrm{~kg}$. Based on these findings and others, the NRC (2012) increased the $\mathrm{Na}$ and $\mathrm{Cl}$ requirement estimates of 7 to $11 \mathrm{~kg}$ pigs to $0.35 \%$ and $0.45 \%$. More recently, Shawk et al. (2018) observed that $0.59 \%$ added salt $(0.34 \% \mathrm{Na}$ and $0.58 \% \mathrm{Cl}$ ) maximized ADG of 7 to $10 \mathrm{~kg}$ pigs. A Na concentration of $0.34 \%$ is similar to the NRC (2012) requirement estimate of $0.35 \%$; however, a $\mathrm{Cl}$ concentration of $0.58 \%$ is significantly greater than the NRC (2012) requirement estimate of $0.45 \%$. When $\mathrm{Na}$ and $\mathrm{Cl}$ are independently evaluated, an accurate requirement estimate for each electrolyte can be determined; however, there is limited research available that documents how the dietary source of the $\mathrm{Na}$ and $\mathrm{Cl}$ influences the requirement. Therefore, the objective of these experiments was to evaluate the effects of source and concentration of $\mathrm{Na}$ and $\mathrm{Cl}$ on the growth performance of nursery pigs weighing $\sim 7$ to $12 \mathrm{~kg}$.

\section{MATERIALS AND METHODS}

\section{General}

The Kansas State University Institutional Animal Care and Use Committee approved the protocol used in these experiments. Pigs were weaned at $\sim 21 \mathrm{~d}$ of age and at this time, randomly allotted to pens. Each pen was equipped with a four-hole, dry self-feeder, and a nipple waterer to provide ad libitum access to feed and water. Exps. 1 and 3 were conducted at the Kansas State University Swine Teaching and Research Center in Manhattan, KS. Exp. 2 was conducted at the Kansas State University Segregated Early Weaning Research Facility in Manhattan KS. All experimental diets were manufactured at the Kansas State University O.H. Kruse Feed Technology Innovation Center.

\section{Experiment 1}

A total of mixed-sex 360 pigs (Line $241 \times 600$; DNA, Columbus, NE; initially $6.9 \mathrm{~kg}$ ) were used in a $14-d$ study. Pigs were fed a common diet $(0.33 \%$ $\mathrm{Na}$ and $0.76 \% \mathrm{Cl}$ ) for $7 \mathrm{~d}$ after weaning. On day 7 after weaning, considered day 0 in the trial, pens of pigs were blocked by BW and randomly assigned to one of four dietary treatments with 15 replications per treatment and six pigs per pen. Each pen was $1.5 \times 1.2 \mathrm{~m}$ providing $0.30 \mathrm{~m}^{2}$ per pig. Four dietary treatments were used to determine if the source of lactose and the source and concentration of $\mathrm{Na}$ and $\mathrm{Cl}$ influence growth performance. Source of lactose was of interest because dried whey is a significant source of $\mathrm{Na}$ and $\mathrm{Cl}$. The four treatments included a $10 \%$ dried whey diet with $0.60 \%$ added salt $(0.37 \% \mathrm{Na}$ and $0.75 \% \mathrm{Cl})$ and three diets with $7.2 \%$ crystalline lactose and either: $0.35 \%$ added salt $(0.18 \% \mathrm{Na}$ and $0.47 \% \mathrm{Cl}), 0.78 \%$ added salt $(0.35 \% \mathrm{Na}$ and $0.72 \% \mathrm{Cl})$, or $1.15 \% \mathrm{NaHCO}_{3}$ and $0.40 \% \mathrm{KCl}(0.35 \% \mathrm{Na}$ and $0.45 \% \mathrm{Cl}$; Table 1$)$. Thus, the dried whey diet and the lactose diet containing $0.78 \%$ added salt contained similar $\mathrm{Na}$ and $\mathrm{Cl}$ concentrations. The lactose diet containing $\mathrm{NaHCO}_{3}$ and $\mathrm{KCl}$ had similar $\mathrm{Na}$ to these diets, but similar $\mathrm{Cl}$ content to the lactose diet containing $0.35 \%$ added salt. Nutrient values and standardized ileal digestibility coefficients of amino acids used in diet formulation were derived from NRC (2012). Experimental diets were fed for 14 d. Pens of pigs were weighed and feed disappearance was recorded on days 0,7 , and 14 to determine ADG, ADFI, andG:F. Dietary treatments were based on corn and soybean meal and were fed in meal form. Dried whey was replaced with crystalline lactose to equalize the lactose content of each diet, and all diets were formulated to the same net energy concentration. Salt, $\mathrm{KCl}$, or $\mathrm{NaHCO}_{3}$ replaced corn to create the experimental diets.

\section{Experiment 2}

A total of 360 barrows (Line $200 \times 400$; DNA, Columbus, NE; initially $7.1 \mathrm{~kg}$ ) were used in a $21-\mathrm{d}$ study. Pigs were fed a common diet $(0.33 \% \mathrm{Na}$ and $0.76 \% \mathrm{Cl}$ ) for $8 \mathrm{~d}$ after weaning. On day 8 after weaning, considered day 0 in the trial, pens of pigs were blocked by body weight and randomly assigned to one of six dietary treatments with 12 replications per treatment and five pigs per pen. Each pen was $1.2 \times 1.2 \mathrm{~m}$ providing $0.28 \mathrm{~m}^{2}$ per pig. Experimental treatments (Table 2) included two added salt diets (providing $0.13 \% \mathrm{Na}$ and $0.35 \% \mathrm{Cl}$ or $0.35 \% \mathrm{Na}$ and $0.68 \% \mathrm{Cl}$ ), three diets with $\mathrm{Na}$ and $\mathrm{Cl}$ provided 
Table 1. Diet composition, Exp. 1 (as-fed basis) ${ }^{1}$

\begin{tabular}{|c|c|c|c|c|}
\hline Lactose source: & $\underline{\text { Dried whey }}$ & & Lactose & \\
\hline Na source: & $0.60 \%$ & $0.35 \%$ & $0.78 \%$ & $\mathrm{NaHCO}_{3}$ \\
\hline $\mathrm{Cl}$ source: & $\mathrm{NaCl}$ & $\mathrm{NaCl}$ & $\mathrm{NaCl}$ & $\mathrm{KCl}$ \\
\hline $\mathrm{Na}, \%$ & 0.37 & 0.18 & 0.35 & 0.35 \\
\hline $\mathrm{Cl}, \%$ & 0.75 & 0.47 & 0.72 & 0.45 \\
\hline \multicolumn{5}{|l|}{ Ingredient, $\%$} \\
\hline Corn & 50.36 & 50.47 & 49.76 & 48.59 \\
\hline Soybean meal ( $48 \%$ crude protein) & 29.65 & 29.67 & 29.66 & 29.65 \\
\hline Lactose & - & 7.20 & 7.20 & 7.20 \\
\hline Dried whey & 10.00 & - & - & - \\
\hline HP $300^{2}$ & 5.00 & 7.75 & 7.80 & 7.88 \\
\hline Choice white grease & 1.00 & 0.90 & 1.15 & 1.55 \\
\hline Monocalcium P $(21 \% \mathrm{P})$ & 1.05 & 1.33 & 1.33 & 1.15 \\
\hline Limestone & 1.05 & 1.05 & 1.05 & 1.15 \\
\hline Potassium chloride & - & - & - & 0.40 \\
\hline Sodium bicarbonate & - & - & - & 1.15 \\
\hline Salt & 0.60 & 0.35 & 0.78 & - \\
\hline Zinc oxide & 0.25 & 0.25 & 0.25 & 0.25 \\
\hline Trace mineral premix ${ }^{3}$ & 0.15 & 0.15 & 0.15 & 0.15 \\
\hline Vitamin premix ${ }^{4}$ & 0.25 & 0.25 & 0.25 & 0.25 \\
\hline Phytase $^{5}$ & 0.02 & 0.02 & 0.02 & 0.02 \\
\hline L-Lysine $\cdot \mathrm{HCl}$ & 0.30 & 0.30 & 0.30 & 0.30 \\
\hline DL-Methionine & 0.18 & 0.17 & 0.17 & 0.17 \\
\hline L-Threonine & 0.15 & 0.16 & 0.16 & 0.16 \\
\hline TOTAL & 100 & 100 & 100 & 100 \\
\hline \multicolumn{5}{|l|}{ Calculated analysis } \\
\hline \multicolumn{5}{|l|}{ Standard ileal digestible AA, \% } \\
\hline Lysine & 1.35 & 1.35 & 1.35 & 1.35 \\
\hline Isoleucine:lysine & 63 & 63 & 63 & 63 \\
\hline Leucine:lysine & 123 & 123 & 123 & 122 \\
\hline Methionine:lysine & 35 & 35 & 35 & 34 \\
\hline Methionine and cystine:lysine & 58 & 58 & 58 & 57 \\
\hline Threonine:lysine & 66 & 65 & 65 & 65 \\
\hline Tryptopahn:lysine & 19.0 & 19.0 & 19.0 & 19.0 \\
\hline Valine:lysine & 67 & 68 & 68 & 68 \\
\hline Total lysine, $\%$ & 1.49 & 1.49 & 1.49 & 1.49 \\
\hline Net energy, $\mathrm{kcal} / \mathrm{kg}$ & 2,447 & 2,448 & 2,448 & 2,447 \\
\hline Crude protein, $\%$ & 22.8 & 23.2 & 23.1 & 23.1 \\
\hline Calcium, $\%$ & 0.78 & 0.78 & 0.78 & 0.78 \\
\hline Phosphorus, \% & 0.68 & 0.69 & 0.69 & 0.65 \\
\hline Available phosphorus, $\%$ & 0.48 & 0.48 & 0.48 & 0.48 \\
\hline Sodium, $\%$ & 0.37 & 0.18 & 0.35 & 0.35 \\
\hline Chloride, $\%$ & 0.75 & 0.47 & 0.72 & 0.45 \\
\hline Potassium, $\%$ & 1.14 & 1.02 & 1.01 & 1.22 \\
\hline $\mathrm{dEB}, \mathrm{mEq} / \mathrm{kg}^{6}$ & 240 & 205 & 207 & 337 \\
\hline \multicolumn{5}{|l|}{ Chemical analysis, $\%$} \\
\hline $\mathrm{DM}$ & 88.45 & 90.12 & 88.83 & 89.22 \\
\hline Crude protein & 19.51 & 22.97 & 20.63 & 21.50 \\
\hline Sodium & 0.37 & 0.18 & 0.37 & 0.37 \\
\hline Chloride & 0.67 & 0.36 & 0.60 & 0.35 \\
\hline
\end{tabular}

${ }^{1}$ Experimental diets were fed from days 7 to 21 after weaning.

${ }^{2}$ Hamlet Protein, Findlay, OH.

${ }^{3}$ Provided per kilogram of diet: $27 \mathrm{mg}$ Mn from manganese oxide, $110 \mathrm{mg}$ Fe from iron sulfate, $110 \mathrm{mg} \mathrm{Zn}$ from zinc sulfate, $11 \mathrm{mg}$ Cu from copper sulfate, $0.20 \mathrm{mg}$ I from calcium iodate, and $0.20 \mathrm{mg}$ Se from sodium selenite.

${ }^{4}$ Provided per kilogram of diet: 4,409 IU vitamin A, $661 \mathrm{IU}$ vitamin $\mathrm{D}_{3}, 18 \mathrm{IU}$ vitamin $\mathrm{E}, 1.8 \mathrm{mg}$ vitamin $\mathrm{K}, 3.3 \mathrm{mg}$ riboflavin, $11.0 \mathrm{mg}$ pantothenic acid, $19.8 \mathrm{mg}$ niacin, and $0.02 \mathrm{mg}$ vitamin $\mathrm{B}_{12}$

${ }^{5}$ Ronozyme HiPhos 2700 (DSM Nutritional Products, Inc., Parsippany, NJ), providing 406.3 phytase units (FTU)/kg and an estimated release of $0.10 \%$ available $P$.

${ }^{6}$ Dietary electrolyte balance; calculated as $=(\mathrm{Na} \times 434.98)+(\mathrm{K} \times 255.74)-(\mathrm{Cl} \times 282.06)$. 
Table 2. Diet composition, Exp. 2 (as-fed basis) ${ }^{1}$

\begin{tabular}{|c|c|c|c|c|c|c|c|}
\hline \multirow{3}{*}{$\begin{array}{l}\text { Na source: } \\
\mathrm{Cl} \text { source: } \\
\mathrm{Na}, \%\end{array}$} & \multirow{2}{*}{\multicolumn{2}{|c|}{$\begin{array}{l}\mathrm{NaCl} \\
\mathrm{NaCl}\end{array}$}} & \multicolumn{4}{|c|}{$\mathrm{NaHCO}_{3}$} & \multirow[b]{4}{*}{ Common Phase 3 diet } \\
\hline & & & \multicolumn{3}{|c|}{$\mathrm{KCl}$} & $\underline{\mathrm{CaCl}_{2}}$ & \\
\hline & 0.13 & 0.35 & 0.13 & 0.35 & 0.57 & 0.35 & \\
\hline $\mathrm{Cl}, \%$ & 0.35 & 0.68 & 0.50 & 0.50 & 0.50 & 0.50 & \\
\hline \multicolumn{8}{|l|}{ Ingredient, $\%$} \\
\hline Corn & 54.72 & 54.72 & 54.72 & 54.72 & 54.72 & 54.72 & 60.28 \\
\hline $\begin{array}{l}\text { Soybean meal ( } 48 \% \text { crude } \\
\text { protein) }\end{array}$ & 23.36 & 23.36 & 23.36 & 23.36 & 23.36 & 23.36 & 34.65 \\
\hline Dried whey ${ }^{4}$ & 10.00 & 10.00 & 10.00 & 10.00 & 10.00 & 10.00 & - \\
\hline HP $300^{5}$ & 5.00 & 5.00 & 5.00 & 5.00 & 5.00 & 5.00 & - \\
\hline Choice white grease & 0.95 & 0.95 & 0.95 & 0.95 & 0.95 & 0.95 & 1.30 \\
\hline Monocalcium P $(21 \% \mathrm{P})$ & 1.10 & 1.10 & 1.10 & 1.10 & 1.10 & 1.10 & 1.15 \\
\hline Calcium carbonate & 0.81 & 0.81 & 0.81 & 0.81 & 0.81 & 0.50 & 0.88 \\
\hline L-Lysine $\cdot \mathrm{HCl}$ & 0.50 & 0.50 & 0.50 & 0.50 & 0.50 & 0.50 & 0.35 \\
\hline DL-Methionine & 0.24 & 0.24 & 0.24 & 0.24 & 0.24 & 0.24 & 0.16 \\
\hline L-Threonine & 0.24 & 0.24 & 0.24 & 0.24 & 0.24 & 0.24 & 0.14 \\
\hline L-Tryptophan & 0.03 & 0.03 & 0.03 & 0.03 & 0.03 & 0.03 & 0.00 \\
\hline L-Valine & 0.12 & 0.12 & 0.12 & 0.12 & 0.12 & 0.12 & 0.04 \\
\hline Trace mineral premix ${ }^{6}$ & 0.15 & 0.15 & 0.15 & 0.15 & 0.15 & 0.15 & 0.15 \\
\hline Vitamin premix ${ }^{7}$ & 0.25 & 0.25 & 0.25 & 0.25 & 0.25 & 0.25 & 0.25 \\
\hline Phytase $^{8}$ & 0.02 & 0.02 & 0.02 & 0.02 & 0.02 & 0.02 & 0.02 \\
\hline Zinc oxide & 0.25 & 0.25 & 0.25 & 0.25 & 0.25 & 0.25 & - \\
\hline $\mathrm{NaHCO}_{3}$ & - & - & 0.18 & 1.00 & 1.80 & 1.00 & - \\
\hline Potassium chloride & - & - & 0.48 & 0.48 & 0.48 & - & - \\
\hline Calcium chloride & - & - & - & - & - & 0.46 & - \\
\hline Salt & 0.13 & 0.68 & - & - & - & - & 0.65 \\
\hline Sand & 2.15 & 1.60 & 1.62 & 0.80 & - & 1.12 & - \\
\hline Total & 100 & 100 & 100 & 100 & 100 & 100 & 100 \\
\hline \multicolumn{8}{|l|}{ Calculated analysis } \\
\hline \multicolumn{8}{|l|}{ Standardized ileal digestible AA, $\%$} \\
\hline Lysine & 1.35 & 1.35 & 1.35 & 1.35 & 1.35 & 1.35 & 1.30 \\
\hline Isoleucine:lysine & 55 & 55 & 55 & 55 & 55 & 55 & 61 \\
\hline Leucine:lysine & 111 & 111 & 111 & 111 & 111 & 111 & 124 \\
\hline Methionine:lysine & 37 & 37 & 37 & 37 & 37 & 37 & 35 \\
\hline Methionine and cystine:lysine & 58 & 58 & 58 & 58 & 58 & 58 & 58 \\
\hline Threonine:lysine & 65 & 65 & 65 & 65 & 65 & 65 & 62 \\
\hline Tryptopahn:lysine & 18.7 & 18.7 & 18.7 & 18.7 & 18.7 & 18.7 & 18.5 \\
\hline Valine:lysine & 68 & 68 & 68 & 68 & 68 & 68 & 69 \\
\hline Total lysine, $\%$ & 1.47 & 1.47 & 1.47 & 1.47 & 1.47 & 1.47 & 1.45 \\
\hline Net energy, kcal $/ \mathrm{kg}$ & 2,447 & 2,447 & 2,447 & 2,447 & 2,447 & 2,447 & 2,451 \\
\hline Crude protein, $\%$ & 20.5 & 20.5 & 20.5 & 20.5 & 20.5 & 20.5 & 22.1 \\
\hline Calcium, \% & 0.71 & 0.71 & 0.71 & 0.71 & 0.71 & 0.71 & 0.7 \\
\hline Phosphorus, \% & 0.65 & 0.65 & 0.65 & 0.65 & 0.65 & 0.65 & 0.65 \\
\hline Available phosphorus, $\%$ & 0.48 & 0.48 & 0.48 & 0.48 & 0.48 & 0.48 & 0.43 \\
\hline Sodium, $\%$ & 0.13 & 0.35 & 0.13 & 0.35 & 0.57 & 0.35 & 0.28 \\
\hline Chloride, $\%$ & 0.35 & 0.68 & 0.50 & 0.50 & 0.50 & 0.50 & 0.50 \\
\hline Potassium, $\%$ & 1.02 & 1.02 & 1.26 & 1.26 & 1.26 & 1.02 & 0.97 \\
\hline Dietary electrolyte balance, $\mathrm{mEq} / \mathrm{kg}^{9}$ & 218 & 221 & 237 & 334 & 428 & 272 & 229 \\
\hline \multicolumn{8}{|l|}{ Chemical analysis, $\%$} \\
\hline DM & 91.07 & 87.89 & 90.26 & 89.22 & 88.85 & 89.34 & - \\
\hline Crude protein & 21.52 & 21.71 & 22.44 & 20.88 & 21.01 & 19.73 & - \\
\hline Sodium & 0.18 & 0.39 & 0.19 & 0.40 & 0.60 & 0.39 & - \\
\hline Chloride & 0.34 & 0.61 & 0.49 & 0.47 & 0.47 & 0.56 & - \\
\hline
\end{tabular}

${ }^{1}$ Experimental diets were fed to pigs from days 7 to 21 after weaning. Sand was removed and replaced with sodium bicarbonate to create the treatment diets. Treatment diets containing $0.18 \%$ and $1.80 \%$ sodium bicarbonate were manufactured and blended at the feed mill to create the intermediate concentrations.

${ }^{2}$ Sodium and $\mathrm{Cl}$ values from NRC (1998) were used for soybean meal. Values for all other ingredients are from NRC (2012).

${ }^{3}$ Common phase 3 diet was fed $7 \mathrm{~d}$ following treatment feeding.

${ }^{4}$ Dried whey was analyzed for dietary $\mathrm{Na}(0.61 \%)$ and $\mathrm{Cl}(1.37 \%)$ and analyzed values were used in formulation.

${ }^{5}$ Hamlet Protein, Findlay, OH.

${ }^{6}$ Provided per kilogram of diet: $27 \mathrm{mg}$ Mn from manganese oxide, $110 \mathrm{mg}$ Fe from iron sulfate, $110 \mathrm{mg} \mathrm{Zn}$ from zinc sulfate, $11 \mathrm{mg}$ Cu from copper sulfate, $0.20 \mathrm{mg}$ I from calcium iodate, and $0.20 \mathrm{mg}$ Se from sodium selenite.

${ }^{7}$ Provided per kilogram of diet: 4,409 IU vitamin A, $661 \mathrm{IU}$ vitamin $\mathrm{D}_{3}, 18 \mathrm{IU}$ vitamin $\mathrm{E}, 1.8 \mathrm{mg}$ vitamin $\mathrm{K}, 3.3 \mathrm{mg}$ riboflavin, $11.0 \mathrm{mg}$ pantothenic acid, $19.8 \mathrm{mg}$ niacin, and $0.02 \mathrm{mg}$ vitamin $\mathrm{B}_{12}$.

${ }^{8}$ Ronozyme HiPhos 2700 (DSM Nutritional Products, Inc., Parsippany, NJ), providing 406.3 phytase units (FTU)/kg and an estimated release of $0.10 \%$ available $\mathrm{P}$.

${ }^{9}$ Calculated as $=(\mathrm{Na} \times 434.98)+(\mathrm{K} \times 255.74)-(\mathrm{Cl} \times 282.06)$. 
by $\mathrm{NaHCO}_{3}$ and $\mathrm{KCl}(0.13 \%, 0.35 \%$, or $0.57 \% \mathrm{Na}$ and $0.50 \% \mathrm{Cl}$ ), and a diet with $\mathrm{NaHCO}_{3}$ and $\mathrm{CaCl}_{2}$ $(0.35 \% \mathrm{Na}$ and $0.50 \% \mathrm{Cl})$. Nutrient values used in diet formulation were derived from NRC (2012) with the exception of $\mathrm{Na}$ and $\mathrm{Cl}$ in soybean meal and dried whey. From $\mathrm{Na}$ and $\mathrm{Cl}$ analysis of ingredients, Shawk et al. (2018) observed the $\mathrm{Cl}$ concentration of soybean meal to be closer to $0.02 \% \mathrm{Cl}$, which is similar to the NRC (1998) value but much lower than the $0.49 \%$ estimated by NRC (2012). Thus, NRC (1998) $\mathrm{Na}$ and $\mathrm{Cl}$ values for soybean meal were used for diet formulation. Before manufacturing treatment diets, dried whey samples were collected at the mill, pooled, subsampled, and submitted for $\mathrm{Na}$ and $\mathrm{Cl}$ analysis (Cumberland Valley Analytical Service, Maugansville, MD). Analyzed $\mathrm{Na}$ and $\mathrm{Cl}$ values for dried whey were then used in diet formulation. Experimental diets were fed for $14 \mathrm{~d}$ with a common diet $(0.28 \% \mathrm{Na}$ and $0.50 \% \mathrm{Cl})$ fed from days 14 to 21. Pens of pigs were weighed and feed disappearance was recorded every $7 \mathrm{~d}$ to determine ADG, ADFI, and G:F. Dietary treatments were corn-soybean meal based and were fed in meal form. Sand was replaced by an equal amount of either salt, $\mathrm{KCl}$, $\mathrm{CaCl}_{2}$, or $\mathrm{NaHCO}_{3}$ to create the treatment diets.

\section{Experiment 3}

A total of mixed-sex 300 pigs (Line $241 \times 600$; DNA, Columbus, NE; initially $7.1 \mathrm{~kg}$ ) were used in a 21-d growth trial. At weaning, pigs were assigned to pens $\left(1.5 \times 1.2 \mathrm{~m}\right.$ providing $0.36 \mathrm{~m}^{2}$ per pig) with five pigs per pen (sex-balanced) and fed a common diet $(0.33 \% \mathrm{Na}$ and $0.77 \% \mathrm{Cl})$ for $7 \mathrm{~d}$ after weaning. On day 7 after weaning, considered day 0 in the trial, pens of pigs were blocked by BW and randomly assigned to one of six dietary treatments with 10 replications per treatment and five pigs per pen. Experimental treatments included a control diet containing $0.33 \% \mathrm{Na}$ and $0.55 \% \mathrm{Cl}$ provided by added salt and five diets with $0.33 \% \mathrm{Na}$ and added $\mathrm{KCl}$ to provide $0.09 \%, 0.21 \%, 0.32 \%, 0.45 \%$, or $0.55 \% \mathrm{Cl}$ (Table 3). Treatment diets were fed for $14 \mathrm{~d}$ with a common diet $(0.18 \% \mathrm{Na}$ and $0.49 \% \mathrm{Cl})$ fed from days 14 to 21 . Nutrient values used in diet formulation were derived from NRC (2012) with the exception of $\mathrm{Cl}$ concentration of soybean meal for which the NRC (1998) value was used. Pens of pigs were weighed and feed disappearance was recorded every $7 \mathrm{~d}$ to determine ADG, ADFI, and G:F. Dietary treatments were corn-soybean mealbased with $7.2 \%$ crystalline lactose and were fed in meal from. Salt, $\mathrm{KCl}$, or $\mathrm{NaHCO}_{3}$ replaced sand to create the different dietary treatments.

\section{Chemical Analysis}

In each experiment, diet samples were collected from six to nine feeders, blended, and subsampled. In Exp. 1, samples were submitted to a commercial laboratory for analysis of $\mathrm{Na}$ and $\mathrm{Cl}$ (Ward Laboratories, Kearney, NE). Briefly, OM and lipids were removed from the samples via $\mathrm{HNO}_{3}, \mathrm{HCl}$, and $\mathrm{H}_{2} \mathrm{O}_{2}$ (Campbell et al., 1991; Wolf et al., 2003) and then analyzed for $\mathrm{Na}$ by inductively coupled plasma spectroscopy (Kovar, 2003). The Cl concentrations were determined by the titration of sliver nitrate until all $\mathrm{Cl}$ ions were precipitated and then the concentration of free silver ions was determined by using a Metrohm 855 Robitic Titrosampler and a Metrohm 6.0430.100 Ag Titrode (Metrohm USA Inc., Riverview, FL; AOAC 969.10, 1990; Kalra et al., 1991; Mills et al., 1991). Samples from Exps. 2 and 3 were also submitted to a commercial laboratory for $\mathrm{Na}$ and $\mathrm{Cl}$ analysis (Cumberland Valley Analytical Service, Maugansville, MD). Sodium samples were ashed, digested with $\mathrm{HNO}_{3}$ and then analyzed via inductively coupled plasma emission spectroscopy (Perkin Elmer 5300 DV ICP, Perkin Elmer, Shelton, CT; AOAC 985.01, 2000). Chloride samples were extracted with $\mathrm{HNO}_{3}$ and then analyzed via potentiometric titration with sliver nitrate using a Metrohm 848 Titrono Plus (Metrohm USA Inc., Riverview, FL). Standard procedures from AOAC (2006) were followed for analysis of moisture (Method 934.01), and CP (Method 990.03; Kansas State University Analytical Laboratory, Manhattan, KS).

\section{Statistical Analysis}

Data for all experiments were analyzed as a randomized complete block design with body weight as the blocking factor. In all studies, data were analyzed using PROC GLIMMIX in SAS (SAS Institute, Inc., Cary, NC) with pen as the experimental unit. The statistical model contained the fixed effect of dietary treatment and the random effect of BW block. Results were considered significant at $P \leq 0.05$ and marginally significant between $P>0.05$ and $P \leq 0.10$.

For Exp. 1, treatment means were separated with the Tukey-Kramer multiple comparison adjustment. For Exp. 2, preplanned contrasts were used to determine the linear and quadratic response of increasing $\mathrm{Na}$ concentration. Preplanned contrasts were also used to determine the source and concentration effect of $\mathrm{Na}$ and $\mathrm{Cl}$ : (1) $0.13 \% \mathrm{Na}$ and $0.35 \% \mathrm{Cl}$ diet provided by added salt vs. $0.35 \%$ $\mathrm{Na}$ and $0.68 \% \mathrm{Cl}$ diet provided by added salt; (2) $0.35 \% \mathrm{Na}$ and $0.50 \% \mathrm{Cl}$ diet provided by $\mathrm{NaHCO}_{3}$ 
Table 3. Diet composition, Exp. 3 (as-fed basis) ${ }^{1}$

\begin{tabular}{|c|c|c|c|c|c|c|c|}
\hline \multirow[b]{2}{*}{ Item } & \multicolumn{4}{|c|}{ Chloride, $\%$} & \multirow[b]{2}{*}{0.55} & \multirow[b]{2}{*}{$0.78 \%$ added salt } & \multirow{2}{*}{$\begin{array}{c}\text { Common phase } \\
3 \operatorname{diet}^{2}\end{array}$} \\
\hline & 0.09 & 0.21 & 0.32 & 0.45 & & & \\
\hline \multicolumn{8}{|l|}{ Ingredient, $\%$} \\
\hline Corn & 47.41 & 47.41 & 47.41 & 47.41 & 47.41 & 47.41 & 62.92 \\
\hline $\begin{array}{l}\text { Soybean meal }(48 \% \text { crude } \\
\text { protein })^{3}\end{array}$ & 29.82 & 29.82 & 29.82 & 29.82 & 29.82 & 29.82 & 33.68 \\
\hline Lactose & 7.20 & 7.20 & 7.20 & 7.20 & 7.20 & 7.20 & - \\
\hline HP $300^{4}$ & 7.80 & 7.80 & 7.80 & 7.80 & 7.80 & 7.80 & - \\
\hline Choice white grease & 1.95 & 1.95 & 1.95 & 1.95 & 1.95 & 1.95 & - \\
\hline Monocalcium P (21\% P) & 1.10 & 1.10 & 1.10 & 1.10 & 1.10 & 1.10 & 1.15 \\
\hline Limestone & 1.30 & 1.30 & 1.30 & 1.30 & 1.30 & 1.30 & 0.95 \\
\hline L-Lysine $\cdot \mathrm{HCl}$ & 0.30 & 0.30 & 0.30 & 0.30 & 0.30 & 0.30 & 0.30 \\
\hline DL-Methionine & 0.17 & 0.17 & 0.17 & 0.17 & 0.17 & 0.17 & 0.12 \\
\hline L-Threonine & 0.16 & 0.16 & 0.16 & 0.16 & 0.16 & 0.16 & 0.12 \\
\hline Zinc oxide & 0.25 & 0.25 & 0.25 & 0.25 & 0.25 & 0.25 & - \\
\hline Trace mineral premix ${ }^{5}$ & 0.15 & 0.15 & 0.15 & 0.15 & 0.15 & 0.15 & 0.15 \\
\hline Vitamin premix ${ }^{6}$ & 0.25 & 0.25 & 0.25 & 0.25 & 0.25 & 0.25 & 0.25 \\
\hline Phytase $^{7}$ & 0.02 & 0.02 & 0.02 & 0.02 & 0.02 & 0.02 & 0.02 \\
\hline Sand & 0.98 & 0.73 & 0.49 & 0.23 & - & 1.35 & - \\
\hline Potassium chloride & - & 0.25 & 0.49 & 0.75 & 0.98 & - & - \\
\hline Sodium bicarbonate & 1.15 & 1.15 & 1.15 & 1.15 & 1.15 & - & - \\
\hline Salt & - & - & - & - & - & 0.78 & 0.35 \\
\hline Total & 100 & 100 & 100 & 100 & 100 & 100 & 100 \\
\hline \multicolumn{8}{|l|}{ Calculated analysis } \\
\hline \multicolumn{8}{|c|}{ Standardized ileal digestible AA, $\%$} \\
\hline Lysine & 1.35 & 1.35 & 1.35 & 1.35 & 1.35 & 1.35 & 1.24 \\
\hline Isoleucine:lysine & 63 & 63 & 63 & 63 & 63 & 63 & 63 \\
\hline Leucine:lysine & 122 & 122 & 122 & 122 & 122 & 122 & 129 \\
\hline Methionine:lysine & 35 & 35 & 35 & 35 & 35 & 35 & 33 \\
\hline $\begin{array}{l}\text { Methionine and } \\
\text { cystine:lysine }\end{array}$ & 58 & 58 & 58 & 58 & 58 & 58 & 57 \\
\hline Threonine:lysine & 65 & 65 & 65 & 65 & 65 & 65 & 63 \\
\hline Tryptopahn:lysine & 19 & 19 & 19 & 19 & 19 & 19 & 19 \\
\hline Valine:lysine & 67 & 67 & 67 & 67 & 67 & 67 & 69 \\
\hline Total lysine, $\%$ & 1.49 & 1.49 & 1.49 & 1.49 & 1.49 & 1.49 & 1.39 \\
\hline Net energy, $\mathrm{kcal} / \mathrm{kg}$ & 2,446 & 2,446 & 2,446 & 2,446 & 2,446 & 2,446 & 2,403 \\
\hline Crude protein, $\%$ & 23.0 & 23.0 & 23.0 & 23.0 & 23.0 & 23.0 & 21.7 \\
\hline Calcium, $\%$ & 0.82 & 0.82 & 0.82 & 0.82 & 0.82 & 0.82 & 0.70 \\
\hline Phosphorus, \% & 0.68 & 0.68 & 0.68 & 0.68 & 0.68 & 0.68 & 0.65 \\
\hline Available phosphorus, $\%$ & 0.51 & 0.51 & 0.51 & 0.51 & 0.51 & 0.51 & 0.43 \\
\hline Sodium, $\%$ & 0.33 & 0.33 & 0.33 & 0.33 & 0.33 & 0.33 & 0.18 \\
\hline Chloride, $\%$ & 0.09 & 0.21 & 0.32 & 0.45 & 0.55 & 0.55 & 0.49 \\
\hline Potassium, $\%$ & 1.01 & 1.14 & 1.26 & 1.40 & 1.51 & 1.01 & 0.96 \\
\hline $\begin{array}{l}\text { Dietary electrolyte balance, } \\
\mathrm{mEq} / \mathrm{kg}^{8}\end{array}$ & 375 & 375 & 375 & 375 & 374 & 244 & 185 \\
\hline \multicolumn{8}{|l|}{ Chemical analysis, $\%$} \\
\hline DM & 88.31 & 88.38 & 89.31 & 88.89 & 89.06 & 88.63 & - \\
\hline Crude protein & 21.21 & 20.14 & 22.72 & 22.28 & 22.07 & 21.96 & - \\
\hline Sodium & 0.32 & 0.30 & 0.30 & 0.28 & 0.42 & 0.26 & - \\
\hline Chloride & 0.15 & 0.24 & 0.32 & 0.46 & 0.45 & 0.47 & - \\
\hline
\end{tabular}

${ }^{1}$ Experimental diets were fed from days 7 to 21 after weaning.

${ }^{2}$ Common phase 3 diet was fed $7 \mathrm{~d}$ following treatment feeding.

${ }^{3}$ Sodium and $\mathrm{Cl}$ values from NRC (1998) were used for soybean meal. Values for all other ingredients are from NRC (2012).

${ }^{4}$ Hamlet Protein, Findlay, OH.

${ }^{5}$ Provided per kilogram of diet: $27 \mathrm{mg} \mathrm{Mn}$ from manganese oxide, $110 \mathrm{mg}$ Fe from iron sulfate, $110 \mathrm{mg} \mathrm{Zn}$ from zinc sulfate, $11 \mathrm{mg} \mathrm{Cu}$ from copper sulfate, $0.20 \mathrm{mg}$ I from calcium iodate, and $0.20 \mathrm{mg}$ Se from sodium selenite.

${ }^{6}$ Provided per kilogram of diet: 4,409 IU vitamin A, $661 \mathrm{IU}$ vitamin $\mathrm{D}_{3}$, $18 \mathrm{IU}$ vitamin $\mathrm{E}, 1.8 \mathrm{mg}$ vitamin $\mathrm{K}, 3.3 \mathrm{mg}$ riboflavin, $11.0 \mathrm{mg}$ pantothenic acid, $19.8 \mathrm{mg}$ niacin, and $0.02 \mathrm{mg}$ vitamin $\mathrm{B}_{12}$.

${ }^{7}$ Ronozyme HiPhos 2700 (DSM Nutritional Products, Inc., Parsippany, NJ), providing 406.3 phytase units (FTU)/kg and an estimated release of $0.10 \%$ available $\mathrm{P}$.

${ }^{8}$ Calculated as $=(\mathrm{Na} \times 434.98)+(\mathrm{K} \times 255.74)-(\mathrm{Cl} \times 282.06)$. 
and $\mathrm{KCl}$ vs. $0.35 \% \mathrm{Na}$ and $0.50 \% \mathrm{Cl}$ diet provided by $\mathrm{NaHCO}_{3}$ and $\mathrm{CaCl}_{2}$; (3) $0.13 \% \mathrm{Na}$ and $0.50 \% \mathrm{Cl}$ diet provided by $\mathrm{NaHCO}_{3}$ and $\mathrm{KCl}$ vs. $0.13 \% \mathrm{Na}$ and $0.35 \% \mathrm{Cl}$ diet provided by added salt; and (4) $0.35 \% \mathrm{Na}$ and $0.50 \% \mathrm{Cl}$ diet provided by $\mathrm{NaHCO}_{3}$ and $\mathrm{KCl}$ vs. $0.35 \% \mathrm{Na}$ and $0.50 \% \mathrm{Cl}$ diet provided by $\mathrm{NaHCO}_{3}$ and $\mathrm{CaCl}_{2}$ vs. $0.35 \% \mathrm{Na}$ and $0.68 \% \mathrm{Cl}$ diet provided by added salt.

For Exp. 3, linear and quadratic contrasts were used to evaluate increasing $\mathrm{Cl}$. Additionally, the $0.78 \%$ added salt control and $0.55 \% \mathrm{Cl}$ treatment provided by $\mathrm{KCl}$ were compared. Chloride dose-response curves for ADG, ADFI, and G:F were predicted following the procedure described by Goncalves et al. (2016) and using PROC GLIMMIX and PROC NLMIXED in SAS (SAS Institute, Inc., Cary, NC). Linear, quadratic polynomial (QP), broken-line linear (BLL), and broken-line quadratic were the dose-response models that were evaluated. The best-fitting model was determined by using the Bayesian Information Criterion (BIC) with a decrease of two or more units indicating a better fit (Raftery, 1996). Models accounting for heterogeneous residual variances were used when they improved model fit. For the best-fitting models, the response curves and individual pen means were plotted. The breakpoints and $95 \%$ CI were reported for the BLL models. The maximum response and 95\% CI were reported for the QP model. The CI of the QP model was calculated by plotting the regression equation with the 95\% CI across doses and projecting the maximum response across the $y$-axis via a horizontal line. The intersection between the horizontal line and CI boundaries of the predicted line is then projected onto the $x$-axis to estimate the CI of the optimum dose (Goncalves et al., 2016).

\section{RESULTS AND DISCUSSION}

\section{Chemical Analysis}

For Exp. 1, chemical analysis indicated that the dietary $\mathrm{Na}$ concentration of the treatment diets was similar to formulated values, but the analyzed $\mathrm{Cl}$ concentrations were slightly less than formulated (Table 1). From $\mathrm{Na}$ and $\mathrm{Cl}$ analysis of ingredients, Shawk et al. (2018) observed the $\mathrm{Cl}$ concentration of soybean meal to be closer to $0.02 \% \mathrm{Cl}$, which is similar to the NRC (1998) value, but much lower than the $0.49 \%$ estimated by NRC (2012). This explained the discrepancy between formulated and analyzed $\mathrm{Cl}$ values. For Exp. 2, results of the chemical analysis indicated that $\mathrm{Na}$ concentration of the diets was slightly greater than formulated values but followed similar patterns as the designed treatment structure (Table 2). Dietary $\mathrm{Cl}$ concentrations were similar to the calculated values. For Exp. 3, chemical analysis indicated that the dietary $\mathrm{Na}$ and $\mathrm{Cl}$ concentrations of the treatment diets were reasonably similar to formulated values (Table 3).

\section{Experiment 1}

From days 0 to 14 , pigs fed the $0.78 \%$ added salt-lactose diet had greater $(P<0.05)$ ADG than pigs fed the $0.35 \%$ added salt-lactose diet, with intermediate performance observed for pigs fed the $0.60 \%$ added salt-dried whey diet and $1.15 \% \mathrm{NaHCO}_{3}$ and $0.40 \%$ KCl-lactose diet (Table 4). Pigs fed the $0.60 \%$ added salt-dried whey diet had greater ADFI $(P<0.05)$ compared to those fed the $0.35 \%$ added salt-lactose diet, with pigs fed the other treatments intermediate. There was no evidence to indicate that dietary treatment influenced G:F or final BW.

Table 4. Effects of $\mathrm{Na}$ and $\mathrm{Cl}$ source and concentration on nursery pig performance, Exp. $1^{1}$

\begin{tabular}{|c|c|c|c|c|c|}
\hline Lactose source: & Dried whey & & Lactose & & \\
\hline $\begin{array}{l}\text { Na source: } \\
\text { Cl source: }\end{array}$ & $0.60 \% \mathrm{NaCl}$ & $0.35 \% \mathrm{NaCl}$ & $0.78 \% \mathrm{NaCl}$ & $\begin{array}{c}\mathrm{NaHCC} \\
\mathrm{KCl} \\
\end{array}$ & \\
\hline $\mathrm{Na}, \%$ & 0.37 & 0.18 & 0.35 & 0.35 & \\
\hline $\mathrm{Cl}, \%$ & 0.75 & 0.47 & 0.72 & 0.45 & SEM \\
\hline \multicolumn{6}{|l|}{ Days 0 to 14} \\
\hline ADG, $\mathrm{g}$ & $281^{\mathrm{ab}}$ & $251^{\mathrm{b}}$ & $287^{\mathrm{a}}$ & $270^{\mathrm{ab}}$ & 9.5 \\
\hline ADFI, $g$ & $445^{\mathrm{a}}$ & $390^{\mathrm{b}}$ & $427^{\mathrm{ab}}$ & $408^{\mathrm{ab}}$ & 11.2 \\
\hline G:F, g/kg & 631 & 643 & 671 & 661 & 13.1 \\
\hline \multicolumn{6}{|l|}{$\mathrm{BW}, \mathrm{kg}$} \\
\hline Day 0 & 6.9 & 6.9 & 6.9 & 6.9 & 0.06 \\
\hline Day 14 & 10.9 & 10.5 & 11.0 & 10.7 & 0.15 \\
\hline
\end{tabular}

${ }^{\mathrm{ab}}$ Means with common superscripts $\operatorname{differ}(P<0.05)$

${ }^{1}$ A total of 360 barrows (Line $241 \times 600$; DNA, Columbus, NE) were used in a 14-d study with six pigs per pen and 15 pens per treatment. Pigs were weaned at $\sim 21 \mathrm{~d}$, fed a common starter diet for $7 \mathrm{~d}$ post-weaning, then placed on experimental diets. 
The NRC (2012) $\mathrm{Na}$ and $\mathrm{Cl}$ requirement estimates for 7 to $11 \mathrm{~kg}$ pigs are $0.35 \%$ and $0.45 \%$, respectively. Based on the chemical analysis, the $0.78 \%$ added salt-lactose diet (analyzed $0.37 \% \mathrm{Na}$ and $0.60 \% \mathrm{Cl}$ ) and $0.60 \%$ added salt-dried whey diet (analyzed $0.37 \% \mathrm{Na}$ and $0.67 \% \mathrm{Cl}$ ) met the NRC (2012) requirement estimate for $\mathrm{Na}$ and exceeded the $\mathrm{Cl}$ requirement estimate. The $\mathrm{NaHCO}_{3}$ and $\mathrm{KCl}$ diet (analyzed $0.37 \% \mathrm{Na}$ and $0.35 \% \mathrm{Cl}$ ) would have met the NRC (2012) requirement estimate for $\mathrm{Na}$; however, it would be considered deficient in $\mathrm{Cl}$ based on the chemical analysis, even though the formulated target was to meet the NRC (2012) requirement estimate. The numerically decreased ADG and ADFI of pigs fed the $\mathrm{NaHCO}_{3}$ and $\mathrm{KCl}$ diet compared with those fed $0.78 \%$ added salt-lactose diet could be due to the $\mathrm{Na}$ and $\mathrm{Cl}$ source $\left(\mathrm{NaHCO}_{3}\right.$ and $\mathrm{KCl}$ ) or a deficiency of $\mathrm{Cl}$. In two separate studies, Mahan et al. (1999) noted improvements in ADG and $\mathrm{N}$ retention up to a dietary $\mathrm{Cl}$ concentration of $0.32 \%$ and $0.38 \%$ in corn-soybean meal diets with lactose, spray-dried animal plasma, and added $\mathrm{HCl}$. However, in a different study, Mahan et al. (1999) observed improvements in ADG up to a dietary $\mathrm{Cl}$ concentration of $0.45 \%$ in corn-soybean meal diets with lactose and spray dried animal plasma and added $\mathrm{Na}_{2} \mathrm{PO}_{4}$ and $\mathrm{HCl}$. Overall, results of this trial indicate pigs fed an added salt diet that contains a $\mathrm{Na}$ concentration of $0.35 \%$ and a $\mathrm{Cl}$ concentration of $0.60 \%$ had greater growth performance compared to pigs fed a diet deficient in $\mathrm{Na}$ and $\mathrm{Cl}$ based on the NRC (2012) requirement estimate. However, more research is needed to investigate the source effect of $\mathrm{Na}$ and $\mathrm{Cl}$ and to verify the growth responses to $\mathrm{Cl}$ deficiency, which led us to conduct the following two experiments.

\section{Experiment 2}

From days 0 to 14 ( $\sim$ to $11 \mathrm{~kg})$, ADG and ADFI improved (quadratic, $P<0.05$ ) as dietary $\mathrm{Na}$ concentration increased from $0.13 \%$ to $0.35 \%$, with no further benefits observed thereafter (Table 5). Day $14 \mathrm{BW}$ tended $(P=0.089)$ to increase as dietary $\mathrm{Na}$ concentration increased from $0.13 \%$ to $0.35 \%$, with no further benefits observed thereafter. G:F was not influenced by the dietary $\mathrm{Na}$ concentration. There was no evidence to indicate differences in growth performance due to $\mathrm{Na}$ or $\mathrm{Cl}$ source.

From days 14 to 21 when pigs were fed a common diet, pigs previously fed increasing $\mathrm{Na}$ had decreased (linear, $P<0.05$ ) ADG and G:F regardless of $\mathrm{Na}$ source. It is likely that pigs previously fed $0.13 \% \mathrm{Na}$ had compensatory gain compared with pigs previously fed $0.35 \% \mathrm{Na}$; however, pigs fed $0.57 \% \mathrm{Na}$ had consistently poorer growth performance than other treatments during both periods. Previous source and concentration of $\mathrm{Cl}$ did not affect subsequent $\mathrm{ADG}$

Table 5. Effects of $\mathrm{Na}, \mathrm{K}$, and $\mathrm{Cl}$ source and concentrations on nursery pig performance, Exp. $2^{1}$

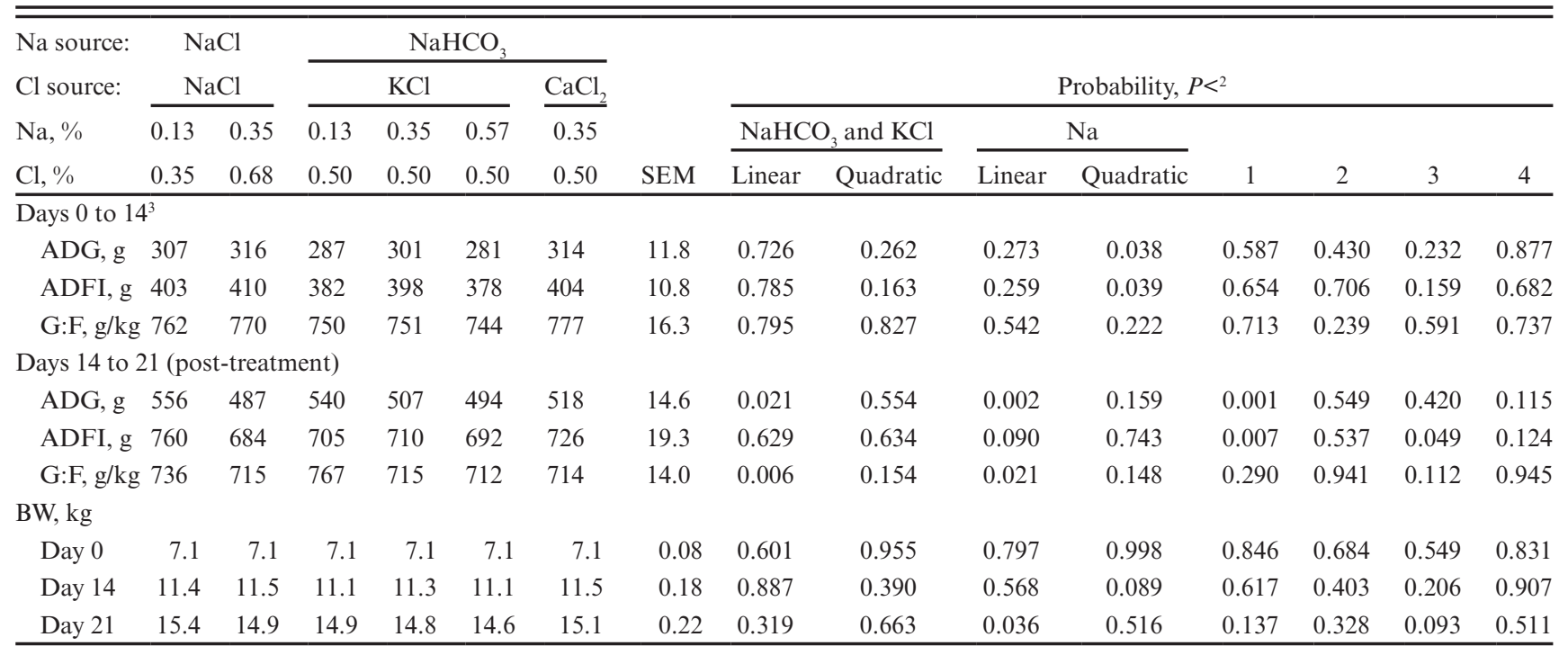

${ }^{1}$ A total of 360 barrows (Line $200 \times 600$; DNA, Columbus, NE) were used in a 14-d study with five pigs per pen and 12 pens per treatment. Pigs were weaned at $\sim 21 \mathrm{~d}$, fed a common starter diet for $7 \mathrm{~d}$ post-weaning, then placed on experimental diets.

${ }^{2}$ Contrasts were (1) $0.13 \% \mathrm{Na}$ and $0.35 \% \mathrm{Cl}$ provided by added salt vs. $0.35 \% \mathrm{Na}$ and $0.68 \% \mathrm{Cl}$ provided by added salt (2) $0.35 \% \mathrm{Na}$ and $0.50 \% \mathrm{Cl}$ provided by $\mathrm{NaCHCO}_{3}$ and $\mathrm{KCl}$ vs. $0.35 \% \mathrm{Na}$ and $0.50 \% \mathrm{Cl}$ provided by $\mathrm{NaHCO}_{3}$ and $\mathrm{CaCl}_{2}$, (3) $0.13 \% \mathrm{Na}$ and $0.50 \% \mathrm{Cl}$ provided by $\mathrm{NaCHCO}$ and $\mathrm{KCl}$ vs. $0.13 \% \mathrm{Na}$ and $0.35 \% \mathrm{Cl}$ provided by $\mathrm{NaCl}$, and (4) $0.35 \% \mathrm{Na}$ and $0.50 \% \mathrm{Cl}$ provided by $\mathrm{NaHCO}_{3}$ and $\mathrm{KCl}$ vs. $0.35 \% \mathrm{Na}$ and $0.50 \% \mathrm{Cl}$ provided by $\mathrm{NaHCO}_{3}$ and $\mathrm{CaCl}_{2}$ vs. $0.35 \% \mathrm{Na}$ and $0.68 \% \mathrm{Cl}$ provided by $\mathrm{NaCl}$.

${ }^{3}$ Experimental diets were fed from days 0 to 14 and a common phase 3 diet was fed from days 14 to 21 . 
or G:F. Pigs previously fed $0.13 \% \mathrm{Na}$ and $0.35 \% \mathrm{Cl}$ provided by $\mathrm{NaCl}$ had increased $(P=0.049)$ ADFI compared with those previously fed $0.13 \% \mathrm{Na}$ and $0.50 \% \mathrm{Cl}$ from $\mathrm{NaHCO}_{3}$ and $\mathrm{KCl}$, potentially due to a compensatory gain from $\mathrm{Cl}$ deficiency.

Overall, the most consistent response observed in this experiment was improvement in growth performance up to a $\mathrm{Na}$ concentration of $0.35 \%$. This observation is in agreement with the NRC (2012) requirement estimate and confirmed the findings from Exp. 1. In this experiment, there was no evidence to indicate that the source of $\mathrm{Na}$ and $\mathrm{Cl}$ ion influenced the growth performance of the pigs. However, it is surprising that there were no statistical differences between the two added salt diets $(0.13 \%$ and $0.35 \% \mathrm{Na})$.

\section{Experiment 3}

From days 0 to 14 ( $\sim$ to $12 \mathrm{~kg}), \mathrm{ADG}, \mathrm{ADFI}$, $\mathrm{G}: \mathrm{F}$, and day $14 \mathrm{BW}$ improved (quadratic, $P<0.05$ ) as dietary $\mathrm{Cl}$ concentration increased from $0.09 \%$ to $0.32 \%$ with no further benefits observed thereafter (Table 6). Pigs fed the $0.55 \% \mathrm{Cl}$ diet had similar ADG, increased $(P=0.046)$ ADFI, but a tendency for poorer $(P=0.069) \mathrm{G}: \mathrm{F}$ compared with pigs fed the control diet with $0.55 \% \mathrm{Cl}$ from added salt. From days 14 to 21 when pigs were fed a common diet, compensatory gain was observed for pigs previously fed the low-chloride diets. ADG decreased (linear, $P=0.045$ ), ADFI increased (linear, $P=0.033$ ), and $\mathrm{G}: \mathrm{F}$ decreased (quadratic, $P=0.004$ ) with increasing dietary $\mathrm{Cl}$ previously fed from days 0 to 14 . Pigs previously fed the $0.55 \% \mathrm{Cl}$ from $\mathrm{KCl}$ diet had greater $(P=0.009)$ ADFI and tended $(P=0.080)$ to have poorer $\mathrm{G}: \mathrm{F}$ than pigs previously fed the diet with $0.55 \% \mathrm{Cl}$ from added salt. For overall period (days 0 to 21), increasing dietary $\mathrm{Cl}$ concentration during days 0 to 14 increased overall ADG (quadratic, $P=0.002$ ) and ADFI (linear, $P=0.002$ ), but did not affect overall G:F. Pigs fed the $0.55 \% \mathrm{Cl}$ from $\mathrm{KCl}$ diet during days 0 to 14 had greater $(P=0.006)$ overall ADFI but decreased $(P=0.017)$ overall $\mathrm{G}: F$ compared with pigs fed the diet with $0.55 \% \mathrm{Cl}$ from added salt.

From days 0 to 14 , the BLL model was the best fitting model for ADG and ADFI and indicated a breakpoint of $0.23 \% \mathrm{Cl}$ (Figures 1 and 2). For the ADG BLL model, ADG, $g=357.87-$ $619.42 \times(0.23-\mathrm{Cl}, \%)$ when $\mathrm{Cl}<0.23 \%$ and $\mathrm{ADG}$, $g=359.5$ when $\mathrm{Cl} \geq 0.23 \%$. For the ADFI BLL model, ADFI, $g=494.45-415.5 \times(0.23-\mathrm{Cl}, \%)$ when $\mathrm{Cl}<0.23 \%$ and ADFI, $g=495.2$ when $\mathrm{Cl} \geq$ $0.23 \%$. The best-fitting model for G:F was the QP

Table 6. Effects of increasing $\mathrm{Cl}$ for 7 to $12 \mathrm{~kg}$ nursery pigs on growth performance, Exp. $3^{1}$

\begin{tabular}{|c|c|c|c|c|c|c|c|c|c|c|}
\hline \multirow[b]{3}{*}{ Item } & \multirow{2}{*}{\multicolumn{5}{|c|}{ Chloride, $\%{ }^{2}$}} & \multirow{3}{*}{$\begin{array}{c}0.78 \% \\
\text { added salt } \\
\operatorname{diet}^{3}\end{array}$} & \multirow[b]{3}{*}{ SEM } & \multicolumn{3}{|c|}{ Probability, $P<$} \\
\hline & & & & & & & & \multirow{2}{*}{$\begin{array}{c}0.78 \% \\
\text { added salt } \\
\text { diet vs. } \\
0.55 \% \mathrm{Cl} \\
\text { diet }\end{array}$} & \multicolumn{2}{|c|}{$\mathrm{Cl}$} \\
\hline & 0.09 & 0.21 & 0.32 & 0.45 & 0.55 & & & & Linear & Quadratic \\
\hline \multicolumn{11}{|c|}{ Treatment period (days 0 to 14$)^{4}$} \\
\hline ADG, $g$ & 273 & 348 & 372 & 349 & 356 & 351 & 10.0 & 0.676 & 0.001 & 0.001 \\
\hline ADFI, g & 436 & 491 & 507 & 477 & 504 & 469 & 13.6 & 0.046 & 0.003 & 0.035 \\
\hline $\mathrm{G}: \mathrm{F}, \mathrm{g} / \mathrm{kg}$ & 627 & 712 & 734 & 733 & 708 & 749 & 15.8 & 0.069 & 0.001 & 0.001 \\
\hline \multicolumn{11}{|c|}{ Post-treatment period (days 14 to 21 ) } \\
\hline ADG, $\mathrm{g}$ & 554 & 496 & 522 & 497 & 510 & 489 & 14.6 & 0.271 & 0.045 & 0.079 \\
\hline ADFI, $g$ & 789 & 818 & 848 & 817 & 860 & 782 & 20.9 & 0.009 & 0.033 & 0.652 \\
\hline $\mathrm{G}: \mathrm{F}, \mathrm{g} / \mathrm{kg}$ & 704 & 611 & 614 & 609 & 592 & 624 & 13.6 & 0.080 & 0.001 & 0.004 \\
\hline \multicolumn{11}{|c|}{ Overall (days 0 to 21 ) } \\
\hline ADG, $g$ & 367 & 398 & 422 & 399 & 407 & 397 & 7.9 & 0.305 & 0.001 & 0.002 \\
\hline ADFI, $g$ & 554 & 600 & 621 & 591 & 623 & 573 & 13.5 & 0.006 & 0.002 & 0.095 \\
\hline $\mathrm{G}: \mathrm{F}, \mathrm{g} / \mathrm{kg}$ & 664 & 666 & 680 & 676 & 655 & 692 & 11.1 & 0.017 & 0.836 & 0.111 \\
\hline \multicolumn{11}{|l|}{$\mathrm{BW}, \mathrm{kg}$} \\
\hline Day 0 & 7.0 & 7.1 & 7.1 & 7.1 & 7.1 & 7.1 & 0.11 & 0.997 & 0.913 & 0.756 \\
\hline Day 14 & 10.9 & 12.0 & 12.3 & 12.0 & 12.1 & 12.0 & 0.20 & 0.674 & 0.001 & 0.001 \\
\hline Day 21 & 14.7 & 15.4 & 15.9 & 15.5 & 15.6 & 15.4 & 0.24 & 0.362 & 0.004 & 0.006 \\
\hline
\end{tabular}

${ }^{1}$ A total of 300 pigs (Line $241 \times 600$; DNA, Columbus, NE) were used in a 21-d study with five pigs per pen and 10 pens per treatment. Pigs were weaned at $\sim 21 \mathrm{~d}$, fed a common starter diet for $7 \mathrm{~d}$ post-weaning, then placed on experimental diets.

${ }^{2}$ Experimental diets were formulated to a dietary $\mathrm{Na}$ concentration of $0.33 \%$ with $1.15 \%$ sodium bicarbonate and dietary $\mathrm{Cl}$ concentrations were formulated with increasing added potassium chloride.

${ }^{3} 0.78 \%$ added salt diet contained $0.33 \% \mathrm{Na}$ and $0.55 \% \mathrm{Cl}$.

${ }^{4}$ Experimental diets were fed from days 0 to 14 and a common phase 3 diet was fed from days 14 to 21 . 
with the predicted response indicated as $\mathrm{G}: \mathrm{F}, \mathrm{g} /$ $\mathrm{kg}=549.77+1,016.45 \times(\mathrm{Cl}, \%)-1,331.57 \times(\mathrm{Cl}, \%)^{2}$. The maximum performance was achieved at a $\mathrm{Cl}$

BLL BIC $=491.5$

Breakpoint $0.23 \% \mathrm{Cl}$

95\% CI: $[0.18,0.27]$

ADG, $\mathrm{g}=357.87-619.42 \times(0.23-\mathrm{Cl}, \%)$, when $\mathrm{Cl}<0.23 \%$

$\mathrm{ADG}, \mathrm{g}=359.5$, if $\mathrm{Cl} \geq 0.23 \%$

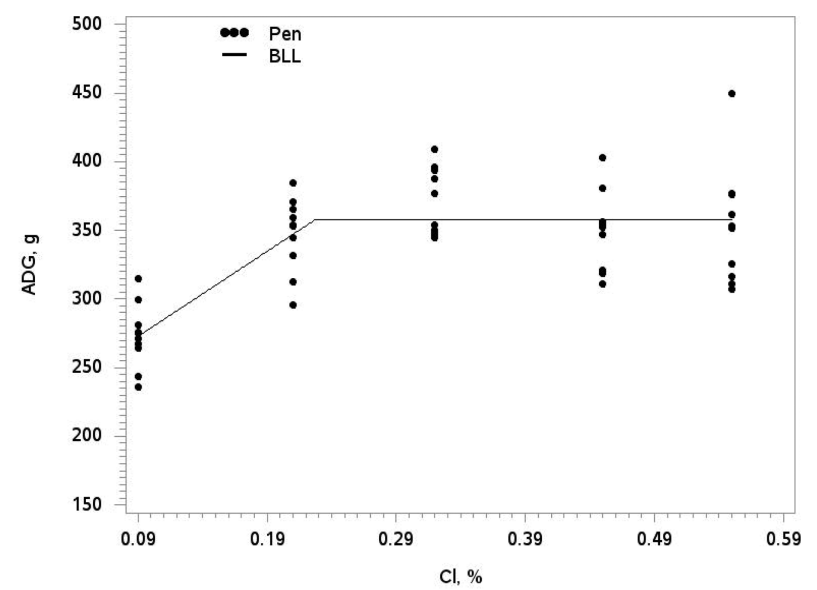

${ }^{1}$ A total of 300 pigs (Line $241 \times 600$; DNA, Columbus, NE) were used with 5 pigs per pen and 10 pens per treatment. Pigs were weaned at approximately $21 \mathrm{~d}$, fed a common starter diet for $7 \mathrm{~d}$ post-weaning, then placed on experimental diets. Experimental diets were fed for $14 \mathrm{~d}$. Linear
polynomial, quadratic polynomial (QP), broken-line linear (BLL), and broken-line quadratic (BLQ) models were fit for the experimental period to estimate the optimal dietary $\mathrm{Cl}$ concentration for ADG. Bayesian Information Criterion (BIC) was used to determine the best fitting model.

Figure 1. Estimated optimal $\mathrm{Cl}$ concentration to maximize ADG for 7 to $12 \mathrm{~kg}$ nursery pigs, Exp. $3^{1}$ concentration of $0.38 \%(95 \% \mathrm{CI}[0.26,0.51 \%])$; however, a $0.23 \% \mathrm{Cl}$ concentration could obtain $96 \%$ of the maximum performance (Figure 3). Maximum ADG could be obtained with a $\mathrm{Cl}$ concentration of $0.23 \%$; however, this would only capture $96 \%$ of the G:F performance. Thus to maximize ADG and G:F, a $\mathrm{Cl}$ concentration of $0.38 \%$ would be needed. $\mathrm{A} \mathrm{Cl}$ concentration of $0.38 \%$ would be slightly less than the current NRC (2012) Cl requirement estimate of $0.45 \%$. The literature has suggested a wide range of $\mathrm{Cl}$ requirements from $0.32 \%$ (Mahan et al., 1999) to 0.50\% (Mahan et al., 1996) for maximum ADG for pigs of weight range tested in the present study. Our requirement estimate for $\mathrm{ADG}(0.23 \%)$ was considerably less than this range. It is worth noting that the studies conducted by Mahan et al. $(1996,1999)$ used $\mathrm{HCl}$ to increase the dietary $\mathrm{Cl}$ concentrations, while $\mathrm{KCl}$ was used in this experiment. It is unknown if the difference in $\mathrm{Cl}$ source would have contributed to the discrepancy among $\mathrm{Cl}$ requirements reported.

In conclusion, results of these studies indicate that $0.35 \% \mathrm{Na}$ (similar to the NRC, 2012 estimates) appears to optimize ADG in pigs from 7 to $11 \mathrm{~kg}$. The optimal $\mathrm{Cl}$ concentration that optimizes ADG was $0.23 \%$ and that of G:F was $0.38 \%$ which are less than NRC (2012) requirement estimate of $0.45 \%$. Source of $\mathrm{Na}$ or $\mathrm{Cl}$ had minimal effect on growth performance.

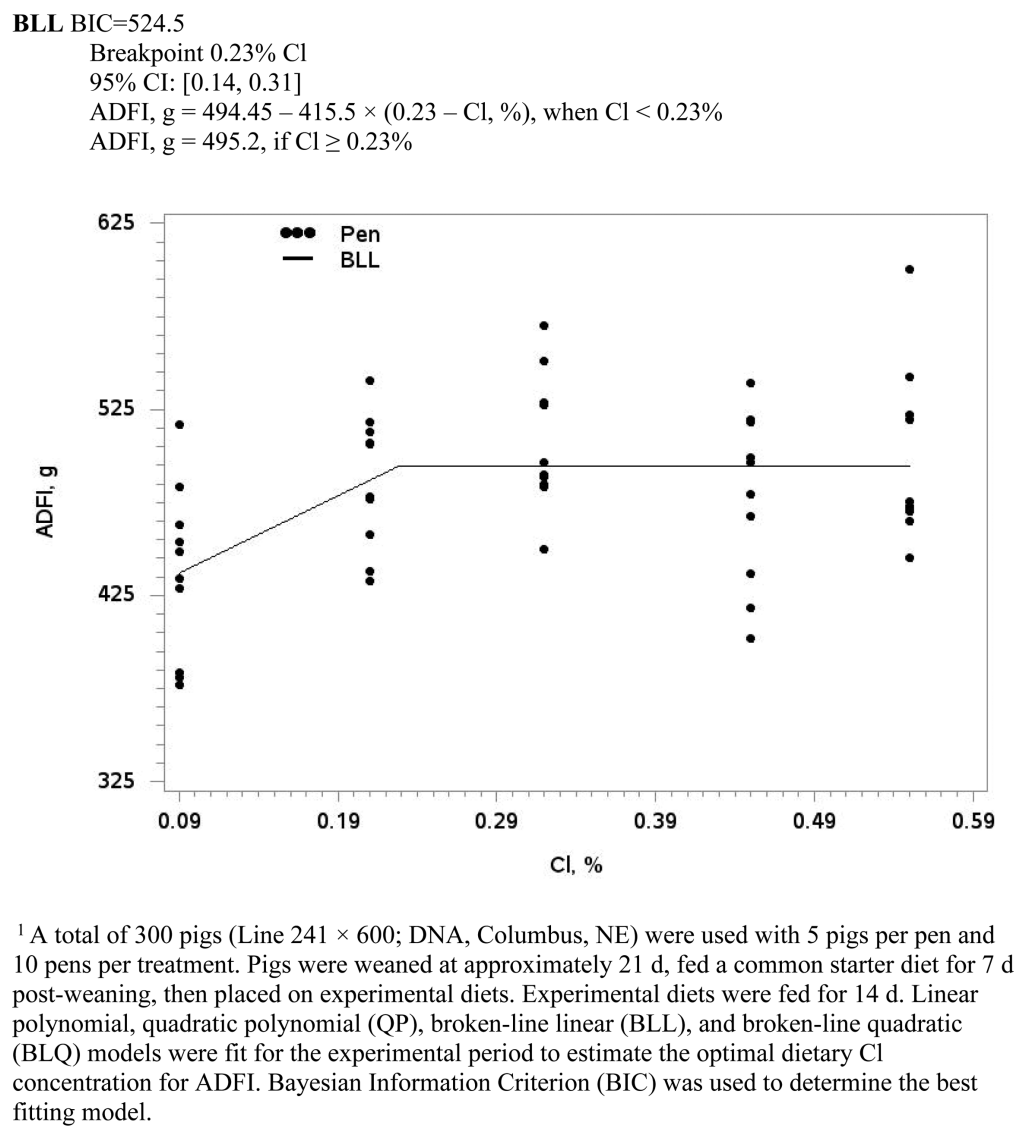

Figure 2. Estimated optimal $\mathrm{Cl}$ concentration to maximize ADFI for 7 to $12 \mathrm{~kg}$ nursery pigs, Exp. $3^{1}$ 
G:F $\quad$ QP BIC $=523.4$

Predicted maximum response at $0.38 \% \mathrm{Cl}(95 \% \mathrm{CI}: 0.26,0.51)$

$96 \%$ of maximum at $0.23 \% \mathrm{Cl}$

$\mathrm{G}: \mathrm{F}, \mathrm{g} / \mathrm{kg}=549.77+1,016.45 \times(\mathrm{Cl}, \%)-1,331.57 \times(\mathrm{Cl}, \%)^{2}$

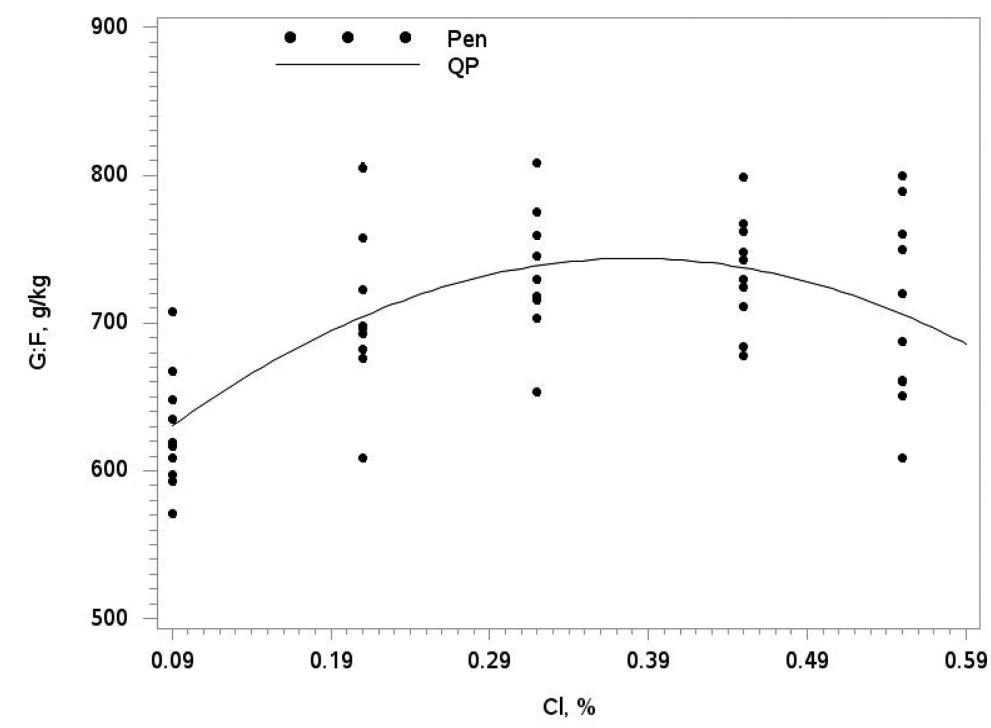

\begin{abstract}
${ }^{1} \mathrm{~A}$ total of 300 pigs (Line $241 \times 600$; DNA, Columbus, NE) were used with 5 pigs per pen and 10 pens per treatment. Pigs were weaned at approximately $21 \mathrm{~d}$, fed a common starter diet for $7 \mathrm{~d}$ post-weaning, then placed on experimental diets. Experimental diets were fed for $14 \mathrm{~d}$. Linear polynomial, quadratic polynomial (QP), broken-line linear (BLL), and broken-line quadratic (BLQ) models were fit for the experimental period to estimate the optimal dietary $\mathrm{Cl}$ concentration for G:F. Bayesian Information Criterion (BIC) was used to determine the best fitting model.
\end{abstract}

Figure 3. Estimated optimal $\mathrm{Cl}$ concentration to maximize G:F for 7 to $12 \mathrm{~kg}$ nursery pigs, Exp. $3^{1}$

\section{LITERATURE CITED}

AOAC. 2000. Official methods of analysis AOAC International. 17th ed. Gaithersburg, MD: Association of Official Analytical Chemistry.

AOAC. 2006. Official methods of analysis AOAC International. 18th ed. Gaithersburg, MD: Association of Official Analytical Chemistry.

Campbell, C. R., and C. O. Plank. 1991. Sample preparation. In: C. Owen Plank, editor, Plant analysis reference procedures for the southern region of the United States. Raleigh NC: Southern Cooperative Series Bulletin \#368. p. 1-11.

Gonçalves, M. A., N. M. Bello, S. S. Dritz, M. D. Tokach, J. M. DeRouchey, J. C. Woodworth, and R. D. Goodband. 2016. An update on modeling dose-response relationships: accounting for correlated data structure and heterogeneous error variance in linear and nonlinear mixed models. J. Anim. Sci. 94:1940-1950. doi:10.2527/jas.2015-0106.

Kalra, Y.P., and D. G. Maynard. 1991. Methods Manual for Forest Soil and Plant Analysis (125 p).Edmonton: Forestry Canada, Northwest region, Northern Forestry Center. Information Report NOR-X-319.

Kovar, J. L. 2003. Method 6.3 inductively coupled plasma spectroscopy. In: J. Peters, editor, Recommended methods of manure analysis. Madison, WI publication A3769: University of Wisconsin-Extension, p. 41-43.

Mahan, D. C., E. A. Newton, and K. R. Cera. 1996. Effect of supplemental sodium chloride, sodium phosphate, or hydrochloric acid in starter pig diets containing dried whey. J. Anim. Sci. 74:1217-1222. doi:10.2527/1996.7461217x
Mahan, D. C., T. D. Wiseman, E. Weaver, and L. Russell. 1999. Effect of supplemental sodium chloride and hydrochloric acid added to initial starter diets containing spray-dried blood plasma and lactose on resulting performance and nitrogen digestibility of 3-week-old weaned pigs. J. Anim. Sci. 77:3016-3021. doi:10.2527/1999.77113016x

Mills, H., A. Jones Jr., and J. Benton. 1991. Chlorine (Cl). In Plant analysis handbook II. Athens, Georgia: MicroMacro Publishing, Inc., p. 39-41.

NRC. 1998. Nutrient requirements of swine. 10th rev. ed. Washington, DC: National Academic Press.

NRC. 2012. Nutrient requirements of swine. 11th rev. ed. Washington, DC: National Academic Press.

Padmore, J. M. 1990. Chlorine (soluble) in animal feed, potentiometric method. In: K. Herlich, editor, Official methods of analysis of the association of official analytical chemists, 15th ed. Arlington, Virginia: AOAC, Inc.

Raftery, A. E. 1996. Approximate Bayes factors and accounting for model uncertainty in generalized linear regression models. Biometrika 83:251-266. doi:10.1093/biomet/83.2.251

Shawk, D. J., R. D. Goodband, M. D. Tokach, S. S. Dritz, J. M. DeRouchey, J. C. Woodworth, A. B. Lerner, and H. E. Williams. 2018. Effects of added dietary salt on pig growth performance. Transl. Anim. Sci. 2:396-406. doi: $10.1093 /$ tas/txy085

Wolf, A., M. Watson, and N. Wolf. 2003. Method 5.4 nitric and hydrochloric acid digestion with peroxide. In: J. Peters, editor, Recommended methods of manure analysis. Madison, WI publication A3769: University of Wisconsin-Extension, p. 35-36. 